\title{
Eating Fermented: Health Benefits of LAB-Fermented Foods
}

\author{
Vincenzo Castellone $^{1, * \mathbb{D}}$, Elena Bancalari ${ }^{1} \mathbb{D}$, Josep Rubert ${ }^{2} \mathbb{D}$, Monica Gatti ${ }^{1} \mathbb{D}$, Erasmo Neviani ${ }^{1} \mathbb{D}$ and \\ Benedetta Bottari ${ }^{1}$ (D)
}

1 Department of Food and Drug, University of Parma, Viale delle Scienze, 49/ A, 43124 Parma, Italy; elena.bancalari@unipr.it (E.B.); monica.gatti@unipr.it (M.G.); erasmo.neviani@unipr.it (E.N.); benedetta.bottari@unipr.it (B.B.)

2 Food Quality and Design Group, Wageningen University, Bornse Weilanden 9, 6708 WG Wageningen, The Netherlands; josep.rubert@wur.nl

* Correspondence: vincenzo.castellone@unipr.it

Citation: Castellone, V.; Bancalari, E.; Rubert, J.; Gatti, M.; Neviani, E.; Bottari, B. Eating Fermented: Health Benefits of LAB-Fermented Foods. Foods 2021, 10, 2639. https:// doi.org/10.3390/foods10112639

Academic Editor: Kavita Sharma

Received: 28 September 2021

Accepted: 27 October 2021

Published: 31 October 2021

Publisher's Note: MDPI stays neutral with regard to jurisdictional claims in published maps and institutional affiliations.

Copyright: (c) 2021 by the authors. Licensee MDPI, Basel, Switzerland. This article is an open access article distributed under the terms and conditions of the Creative Commons Attribution (CC BY) license (https:// creativecommons.org/licenses/by/ $4.0 /)$.

\begin{abstract}
Lactic acid bacteria (LAB) are involved in producing a considerable number of fermented products consumed worldwide. Many of those LAB fermented foods are recognized as beneficial for human health due to probiotic LAB or their metabolites produced during food fermentation or after food digestion. In this review, we aim to gather and discuss available information on the healthrelated effects of LAB-fermented foods. In particular, we focused on the most widely consumed LAB-fermented foods such as yoghurt, kefir, cheese, and plant-based products such as sauerkrauts and kimchi.
\end{abstract}

Keywords: lactic acid bacteria; fermented foods; health benefits; bioactive compounds

\section{Introduction}

Lactic fermented foods have been consumed by humankind since ancient times for their organoleptic characteristics and prolonged shelf-life. Nowadays, the consumption of fermented foods is also driven by a health-related perspective. The market of fermented foods is nowadays touching all countries and shows an increasing trend [1]. Natural microflora of fermented foods is often composed mainly by LAB. LAB are Gram-positive, nonsporing, generally nonmotile, with complex nutritional requirements, depending on the presence of a fermentable carbohydrate for active growth. As an end product of this fermentation, LAB produce copious amounts of lactic acid alone (homofermentative) or together with acetic acid, ethanol, and carbon dioxide (heterofermentative) [2]. Genetic diversity and habitat variation are considerably wide within LAB. Therefore, no general limits for $\mathrm{pH}, \mathrm{a}_{\mathrm{w}}$, temperature, or other parameters exist for the LAB, and the growth-limiting circumstances vary depending on the considered species (Table 1) [3]. LAB are responsible for a great diversification in the flavor and texture of fermented foods, and can be, in some circumstances, responsible for food spoilage [4]. They can also release an array of healthmodulating compounds and signal molecules in the matrix during fermentation. These food-derived bacteria and their metabolites can interact with the intestinal microbiome and with the host itself like members of an orchestra playing a health symphony for the intestine and the organisms in general. Regular ingestion of fermented food can therefore contribute in many ways to homeostasis and organism functions. A link between health and the use of eating LAB-fermented foods has been hypothesized since Metchnikov's intuition that an increased life expectancy of balcanic population was attributable to the significant consumption of lactic fermented milk. Since then, many studies have led to the granting of the probiotic status to different LAB responsible for the fermentation of foods frequently associated with health benefits [5,6]. Many fermented foods are considered functional foods as they contain microorganisms, enhancing the overall health level of consumers [7]. Due to the positive effects exerted both by fermenting microorganisms and 
the products of their metabolism, LAB-fermented foods could represent a safe, unexpensive, and reliable tool in improving human health. This review highlights the health effects reported by the literature on $\mathrm{LAB}$ responsible for the fermentation of different foods, which could contribute to maintaining and promoting consumers' health.

Table 1. Food's LAB groups and characteristics.

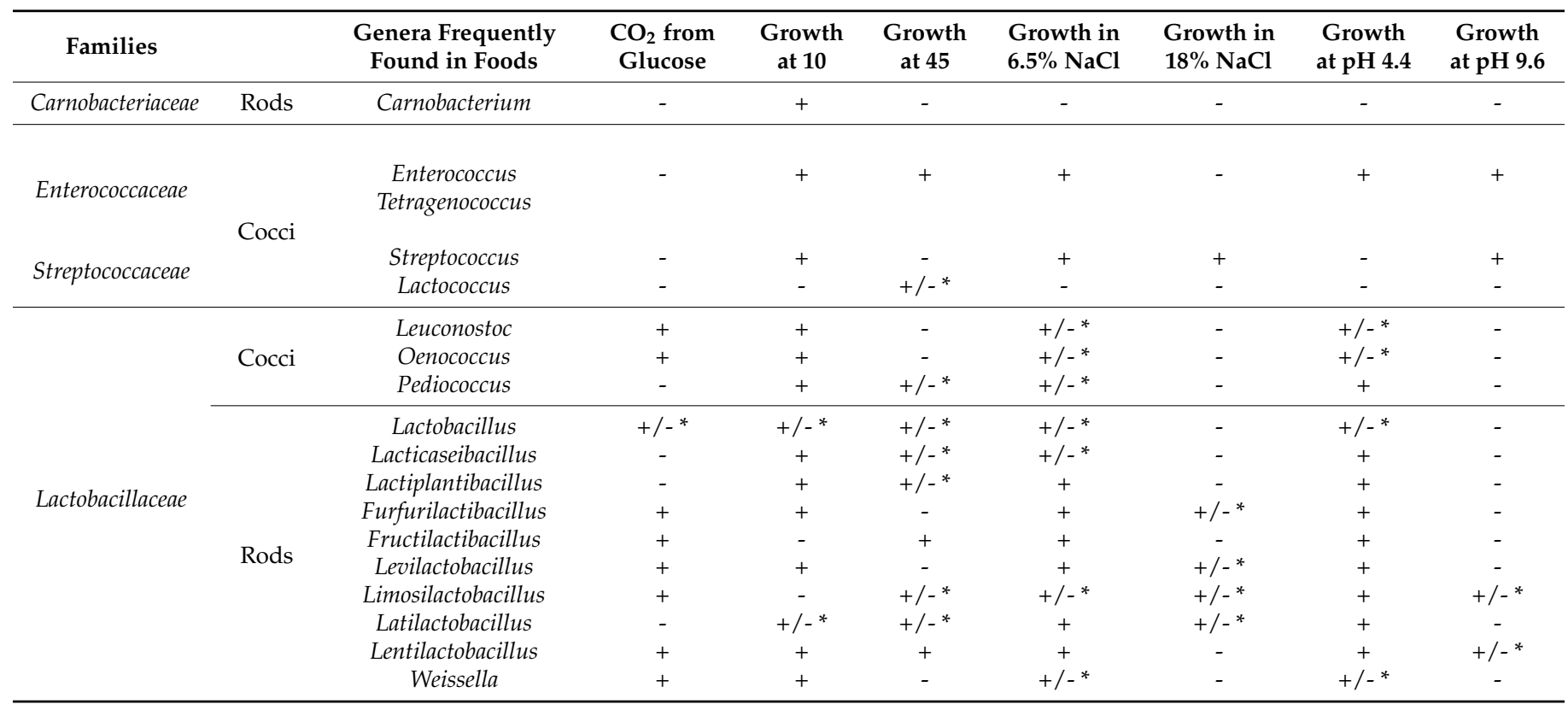

* Response may vary according to strains. "_ absence of the tract. "+" presence of the tract.

\subsection{Lactic Acid Bacteria as Probiotics}

Despite the evolution of the probiotic concept, the term probiotic has been linked to bacteria beneficial for the host health since Elie Metchnikoff's observation that the regular consumption of dairy products fermented by LAB was associated with enhanced health and longevity in the elderly Bulgarian people [8]. Over the years, a considerable number of microorganisms was proposed as probiotics, with health-improving abilities. Most known probiotics belong mainly to the LAB group and Bifidobacteriaceae, while for others such as the yeast Saccharomyces boulardii, or Enteroccoccus spp., the use as probiotic has been debated for long due to their intrinsic opportunistic nature and the possibility to transfer antimicrobial resistance genes $[9,10]$. In contrast to the traditional probiotics, nonconventional, native gut microbiota bacteria have rapidly attracted much more attention for promoting health and therapeutic purposes, leading to the concept of Next-GenerationProbiotics (NGP) [11,12]. Because of the development in microbial culturing techniques [13], in the metagenomics and genomics technologies involved in sequencing [14] and editing of bacterial genome $[15,16]$, the range of microorganisms considered for their potential positive effects on hosts health has nowadays broadened up, involving non-LAB genera like Actinobacteria (Akkermansia muciniphila is among many others an emerging star in the field), Bacteroidetes, Firmicutes, and Verrucomicrobia [12,17]. Despite this, LAB are still the most used health-related bacteria in food production. Due to their long history of safe use, LAB have been listed either as Generally Regarded as Safe (GRAS) at the strain level by the United States Food and Drug Administration (FDA), or as Qualified Presumption of Safety (QPS) at the species level by the European Food Safety Authority (EFSA). Thus, they can be used as food or food supplements [11], and confer to the fermented food functional characteristics, entailing a vast arsenal of aces in the hole in granting benefits to human health [7]. 


\subsection{Health Effects of Probiotics}

Health-related features ascribed to probiotic microorganisms are multifaceted. Probiotics are known for: (i) the production of valuable compounds, (ii) antagonist activity towards pathogenic bacteria, (iii) stimulation and regulation of immune response, and many other effects [2]. As they generally exert their effect starting from the intestine, probiotics should show: (i) good resistance to acids, and (ii) disaggregating effect of biliary salts, (iii) ability to colonize intestinal walls, (iv) compete for nutrients, and (v) remain alive in the harsh and selective conditions of Gastro-Intestinal (GI) tract [2]. By colonizing intestinal mucosa and interacting with the mucus layer, probiotics modulate immune response, improving defense to external attacks. Maintaining a constant presence in the gut, the immune system is stimulated, also leading to reduced severity of autoimmune aggressions and lowering allergic response, according to Rook and the "old friend theory" $[4,5]$. Indeed, in the colonic region, from the fermentation of digested material, they can produce antioxidants and anti-carcinogenic compounds, together with a series of molecules activating a signalling process between bacteria and intestinal epithelium [18]. This starts a cascade of effects that eliminate pathogenic and harmful microorganisms, thus creating a better environment and maintaining homeostasis [2]. To reach these goals, probiotics might be in a viable state and with an adequate amount [19]. However, some experimental evidence suggests a role exerted by non-viable or dead microbial cells in improving the health status of hosts, opening the door to the concepts of post-biotics and para-probiotics [6]. Post-biotics term is referred both to non-viable microorganisms present in the preparation and to soluble compounds released by probiotics after cellular lysis, comprising (i) short-chain fatty acids (SCFA), (ii) lactate, (iii) cellular wall components, and (iv) peptides [20]. Conte et al. reported using post-biotics from different lactobacilli as treatment to reduce the entrance of gluten proteins in $\mathrm{CaCo}-2$ cells of patients affected with celiac disease [20]. Para-probiotics comprise non-viable microorganisms and the entire microbial fraction released after cellular lysis [21]. Sugawara et al., in an intervention study, showed an improvement in intestinal environment and functions after 3 weeks of consumption of a para-probiotics beverage containing non-viable cells of Lactobacillus gasseri [21]. Both viable and non-viable (or part of) cells can interact particularly in the intestinal epithelium through the stimulation of intracellular signalling pathways [22]. Many of these features have been described in $\mathrm{LAB}$, which can produce different compounds, like bioactive sequences of peptides, sugars polymers, and fatty acids involved in boosting human health [11]. LAB can also produce organic acids, bacteriocins, hydrogen peroxide $\left(\mathrm{H}_{2} \mathrm{O}_{2}\right)$, and nitric oxide (NO), that are active against pathogens [10]. Furthermore, during fermentation in the intestinal lumen, LAB also produces SCFA. These acids can be produced also by other microorganisms, for example: acetate can be produced by Akkermansia muciniphila, Bacteroidetes, Bifidobacterium spp., and Clostridium spp.; propionate by Veillonella parvula, Bacteroides eggerthii, Bacteroides fragilis, Ruminococcus bromii, and Eubacterium dolichum; and butyrate by Faecalibacterium prausnitzii, Clostridium leptum, and Eubacterium rectale [23]. SCFA are involved in different processes, for example butyric acids furnish metabolic energy to colonocytes and is studied for its effect in avoiding the development of cancer cells [22]. Propionate enhances gluconeogenesis and helps maintain glucose homeostasis in the organisms by increasing the expression of leptin, an anorectic hormone, in adipocytes [24]. Acetate is involved in the lipogenesis and synthesis of cholesterol [25].

\subsection{Health Effects of Foods Fermented by LAB}

In the past years, the consumption of probiotics was strongly recommended, and the involvement of positive microorganisms in the formulation of foods with a health claim was widespread. Nowadays, due to a more profound knowledge of the probiotics' health effects and the mechanism behind them, it is possible to broaden the range of microorganisms involved in the formulation of functional foods. In some cases, LAB that are part of the spontaneous microbial population of one food, drive the beneficial effects to the host without being recognized (yet) as probiotics [26-29]. Positive effects 
connected to fermented foods have been empirically known for centuries. In many cultures, fermented foods are heritage foods and an integral part of local traditions, probably because fermentation was the only way to preserve foods [29]. Nowadays, regular consumption of fermented foods, especially lactic-fermented ones, has been reported to improve the immune system, reducing the probability of developing morbidities [27] due to a constant communication between bacteria and host immune system. This communication changes the microbial composition of the intestine, maintaining under control pathogenic microflora and meanwhile supporting beneficial microbes populations [30].

Among fermented foods, dairy products have been mainly associated with beneficial effects. This is partly due to the significant number of proteins available in the substrate for cellular duplication. During fermentation, because of acidification and microbial enzymes activity, proteins are denatured and lose their original conformation, releasing sequences of small peptides studied for their potential health-related effects. One of the most studied and regarded groups of bioactive peptides is represented by Angiontensin1-Converting Enzyme (ACE) inhibitors. These bioactive peptides have been studied for their anti-hypertensive effect, and several guidelines suggest consuming fermented dairy products as a non-pharmacological way of controlling hypertension. Scientific evidence reported two main peptides as carriers of hypotensive effect: VPP (valine, proline, proline) and IPP (isoleucine, proline, proline) [29,31,32]. ACE inhibition occurs when ACE I is sequestered by the C-terminal sequence of ACE-inhibitors. In this way, ACE cannot convert angiotensin I in angiotensin II, a potent vasoconstrictor. Synthesis of angiotensin II leads also to degradation of bradykinin, a vasodilator; soaring blood vessels' constriction; and dramatically increasing blood pressure [31,32].

Furthermore, LABs can produce exopolysaccharides (EPS), long sugars polymers formed by repeated units of mono- or oligosaccharides, that are gaining a lot of attention from the scientific community, due to their technological role [33], but also for their promising health benefits [34]. EPS can be divided in two macro-categories depending on the sugars presents in the main chain: (i) Heteropolysaccharides (HePSs) are polymers of different monosaccharides; (ii) Homopolysaccharides (HoPSs) are polymers of one sugar, repeated many times. In the latter case, HoPSs can be divided into glucans or fructans depending on the sugar composing the polymer chain, glucose, and fructose, respectively. Production of HoPS takes place outside microbial cells, mediated by membrane enzymes that hydrolyse and reassemble the sugars in a new EPS chain. By contrast, HePSs synthesis is more complex, and the chain contains more than one sugar moiety, normally being glucose, galactose, and rhamnose. Still, in different LAB's EPS it is possible to find different sugars or other functional groups like acetyl and phosphate groups [35]. Normally, HePSs are associated with the modulation of host function, e.g., antioxidant effect or immune modulation, while HoPSs are associated with prebiotic properties, indicating how the conformation of these branched sugars and the monomeric composition influence the impact on the host $[35,36]$. The prebiotic effect exerted by LAB's EPS is the subject of particular interest, because of the production of SCFA, gasses, and organic acids involved in the inhibition of noxious bacteria and the improvement of host's metabolism [35]. EPS produced by LABs proved to be more effective in increasing the amount of Bifidobacteriaceae in the intestinal lumen with respect to inulin, the most used bifidogenic oligosaccharides. At the same time, an antagonist effect towards Bacteroides and Clostridia was shown. Gut microbiota is strongly affected by the presence of EPS in the intestinal lumen, especially by HoPSs, that result to be the most suitable substrates for fermentation, while HePSs are normally not fermentable, but their ability to modulate the immune system make them of capital importance in maintaining a general health status [36].

In fact, EPS are supposed to have antioxidant and immunomodulatory effects, as well as the ability to reduce cholesterol in the bloodstream and its absorption; anticancer and anti-diabetic effects are just some of the positive features that may be exerted. Furthermore, they also have a role in fighting the presence of harmful bacteria in the intestine, since they can disrupt biofilms, removing the protection of pathogenic microorganisms and 
exposing them to stresses and attacks. Different studies were carried out to explore these proposed effects for EPS. Still, it has to be considered that many of these experiments were carried out in vitro or with animal models, missing the confirmation from clinical trials on humans [36]. Some studies on animals pointed out the anti-cholesterolemic effect of EPS. This effect is based on increasing the high-density lipoprotein (HDL) ratio: total cholesterol with reduction of lipidic deposits in the bloodstream, especially in the aorta. In other experiments, it was observed that bile acids were scavenged by EPS, reducing in this way the amount of cholesterol present in the blood. This can be due also to the utilization of blood cholesterol to synthesize new bile acids, which are subsequently employed in digestion processes. Results are of course promising, even if the mechanism through which EPS lowers cholesterol content in the blood is still not precisely known [36].

Health effects of food fermented by LAB (Figure 1) are known and have been studied for a long time. Despite this, we do not yet know all the mechanisms of action and the secondary effects of LAB and their derived compounds. For many years, literature have focused on health effects of bacteria isolated and recognized as probiotics, but more recent studies shed light on the beneficial effects of bacteria involved in food fermentation that are not considered probiotics due to the non-complete compliance to probiotics guidelines. As an example, LAB proved to be useful in homeostasis both directly in the gut and indirectly utilizing pathways' modifications that lead to an improvement of host health status $[37,38]$.
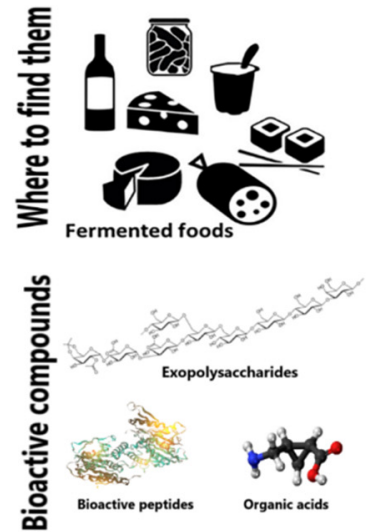
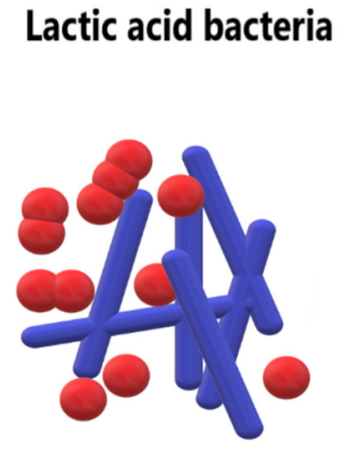

Figure 1. Scheme of LAB bioactive compounds and health-related effects, adapted with permission from [39] Copyright (C) 2018 George, Daniel, Thomas, Singer, Guilbaud, Tessier, Revol-Junelles, Borges and Foligné.

\section{Health-Related Effects of Different LAB Fermented Foods \\ 2.1. Fermented Dairy Products}

Milk is probably one of the first fermented food staples by mankind. Historically, the first fermentations happened accidentally due to unpasteurized milk's tendency to spontaneously ferment due to the high level of nutrients and microbes [40,41]. From a biochemical point of view, fermentation is a complex combination of events. After lactose metabolism, different compounds are generated, such as: acids, ethanol, and carbon dioxide. The production of acids leads to a decrease of the $\mathrm{pH}$, limiting the growth of negative microflora. Aroma compounds are also produced, increasing palatability and acceptance of foods and nutritional compounds like vitamins, minerals, bioactive molecules, and EPS [42]. Nowadays, after millennia of traditions and evolution of dairy art, fermented milk products represent about $20 \%$ of the total revenue generated by the fermented-foods markets all over the world. Production of fermented milks arose after 1950 when the demand for yoghurts and other similar products increased sensibly, attracting the attention of companies and consequently moving the production from a small-scale, in artisanal farms, to a mass production led by big multinationals [42]. Milks from different animals have become raw material for dairy fermentations. In fact, it is possible to find yoghurts, cheeses, and sour milks produced with cow milk, goat, sheep and horse milk 
as just examples in global markets. Even though dairy fermentations originally started from wild LAB present in milk, nowadays companies cannot rely anymore on spontaneous microflora, because of technological properties and possible health issues related to raw materials. For this reason, almost all industrially-fermented dairy products are produced with selected starters, or with back-slopping technique [42-44]. Fermented dairy products can be divided in different categories; in this review, for the sake of brevity, we focus only on fermented milks and cheese. Fermented milks are many and can be classified basing on: production techniques, the origin of milk, and other factors [45]. Since the variety of these products is humongous, considering traditional and industrial processes, novel fermented milks, and ones deeply rooted in archaic societies, we only consider the two most consumed and spread fermented milk products: yoghurt and kefir.

\subsubsection{Yoghurt}

Due to its taste and versatility, yoghurt is one of the most consumed milk-derived products worldwide [46]. Like other dairy products, yoghurt is strongly recommended in diets, for its provided nutrients, like essential amino acids, and bioactive compounds, such as lactic acid, EPS, and liposoluble vitamins [40], which are otherwise rare and difficult to be introduced with the diet [47]. In a standard yoghurt's serving, it is possible to find many useful nutritional compounds like (i) vitamins and minerals in a rapidly absorbable form [48]; (ii) bioactive peptides with many health-modulating effects [29,49]; (iii) branched-chain amino acids (BCAA) positively correlated with muscle growth and body maintenance [50]; (iv) mono- and poly-unsaturated fatty acids vehiculating liposoluble vitamins (A, E, K, and D); and (v) conjugated linoleic acid (CLA), known for the anti-carcinogenic activity and apoptotic induction in cancerous cells, as reported by different papers, especially towards breast cancer in vivo and in vitro [46,51-54]. All the listed compounds, or precursors, are already present in milk, but the fermentation process is essential to liberate this vast amount of positive health-related compounds in the matrix. Fermentation of milk to produce yoghurt is carried out by two specific LAB: Lactobacillus delbrueckii subsp. bulgaricus and Streptococcus thermophilus, even if other species can be added as a plus. Bacteria from yoghurt are known for making part of the so-called transient microbiota, since they usually cannot colonize the intestine. Despite this, the health contribution of yoghurt microflora should not be underrated. Kousgard et al. reported a clinical trial on patients affected with pouchitis and treated with a fecal microbiota transplant. In that study, four out of four patients with pouchitis symptoms remission regularly consumed yoghurt, while only one out of five patients with relapse issues consumed yoghurt on a daily basis [55]. The remission effect could also be correlated to the presence of organic acids produced by microorganisms, which contribute to fighting pathogenic microorganisms and maintaining a safer gut environment. Several dietary guidelines suggest the implementation of yoghurt in a healthy diet daily, also for lactose-sensitive people, due to the ability of the contained LAB species to improve this sugar digestion [56]. Different scientific papers focused on the utilization of probiotic fortified yoghurts in the management of type 2 diabetes. At the same time, Barengolts et al. in a meta-analysis of randomized controlled trials demonstrated that consumption of yoghurt can improve management of diabetes complications, reporting no difference between effects exerted by conventional and probiotic fortified yoghurts [57]. Kong et al. reported the utilization of yoghurt in combination with fruits and caloric restriction to fight non-alcoholic-fattyliver-disease (NAFLD). Their data showed the ability of the diet intervention to modify the gut microbiota. An intimate relationship between gut and liver is already well known to the scientific community. In fact, results from that research paper highlighted how modifications in gut microbial population can retard or even prevent the start of different chronic diseases, like NAFLD, among others [58]. Liu et al. in clinical tests on mice reported traditional yoghurt being able to modulate intestinal microflora, repairing and avoiding dysbiosis that can negatively affect brain functions and behaviour. In fact, in transgenic mice modified to develop Alzheimer disease' (AD) symptoms in early stage of 
life, yoghurt's supplementation reduces the deposition of myeloid-beta plaques in brain cortex and hippocampus, event though it is highly correlated with the onset and development of AD disease. It derives that gut microbiota modulation, operated by ingestion of yoghurt, and its microbiome can help in reducing the issues connected with AD and cognitive function $[59,60]$. Considering all these health-related effects, yoghurt reveals to be a cost-effective way to introduce in the diet countless health-boosting compounds, it helps in the management of non-communicable disease, and is negatively associated with all-cause mortality [60-62].

\subsubsection{Kefir}

It is one of the first fermented milks. Traditional kefir owes its longevity in human diet and traditions to its peculiar organoleptic characteristics and to an unconscious association with health benefits and life prolongation [63]. Traditionally, kefir is made by the action of kefir grains, in which are comprised LAB, Acetic Acid Bacteria (AAB), and yeasts enveloped in a slimy matrix composed of EPS and proteins [64]. Kefir can be defined as a "natural complex probiotic" because of the interaction between many different microorganisms, and it is supposed to exert anticarcinogenic, immunomodulatory, antiallergenic, antidiabetic, antistress, and antiasthmatic effects [65-67]. Kefir microflora depends not only on the inoculum of the grains, but also on external factors (light, temperature, kefir grains/milk ratio, agitation ... ), which can influence organoleptic features as well as bioactivities, favouring the growth of specific strains, while a core population always exists [68]. Healthrelated effects of kefir can be ascribed to the presence of bacteria, but also to bioactivities [69]. It can, for example, modulate gut microbiota and increase Lactobacillus and Bifidobacterium, while decreasing Bacteroidetes level in the intestine of patients affected with metabolic syndrome, leading to improvements in fasting glycaemia, reduction of inflammation signals, and blood pressure [70]. Modifications of the gut microbiota exerted by kefir's bacteria are reported also by Yilmaz et al., who noticed in a randomized control trial that Lentilactobacillus kefiri LK9 was able to colonize the intestine of volunteers after 1 month of administration, resulting as present in faeces at $10^{5}-10^{6} \mathrm{Log} C F U / g$. L. kefiri is also reported to inhibit other microorganisms associated with the start of pro-inflammatory chain events and gastrointestinal illness [71]. Kim et al. investigated the effect of kefir in reducing the incidence of obesity, induced by a high-fat diet (HFD) and NAFLD. In their experiments, results show a decrease of $60 \%$ of incidence of obesity in mice concerning control group, showing that a $0.2 \mathrm{~mL}$ supplementation of kefir reduces the effects of HFD and related NAFLD. Also, blood cholesterol and systemic inflammation, both induced by a fat-rich diet, were reduced by kefir supplementation. The mechanism of action in the reduction of obesity and related problems seems to be exerted by the cooperation of three different factors: LAB, yeasts, and EPS. In fact, kefir-derived bacteria can influence the gut microbiota directly by colonizing gut epithelium and indirectly by modifying $\mathrm{pH}$ of the intestinal lumen and inducing expression of genes that codify for useful enzymes. Reduction of $\mathrm{pH}$ creates a harsh environment for pathogenic and undesired microorganisms, but not for LAB that are normally used in acidic environments. In the same experiments, Kim et al. concluded that the introduction of probiotics derived from natural kefir is able to up-regulate peroxisome proliferator-activate receptor. This system plays a central role in beta-oxidation and reveals to be a fundamental drug helping in fighting NALFD [72,73]. Many studies in recent years focused on anti-cancer abilities of fermented foods, and kefir is one of the most investigated since its health-boosting effects have been known from the dawn of time. Anti-cancer activities exerted by kefir are mediated by different compounds, like bioactive peptides, EPS, and sphingolipids. The mechanism of action of these compounds seems to be bound to modulation of signalling pathways and of cells' processes, e.g., cellular proliferation and apoptosis [65,74]. In a systematic review of the literature, Rafie et al. reported that according to the state of the art, the mechanism of the action exerted by kefir in inducing apoptosis is not fully understood yet, but it can be due to the formation of reactive oxygen species (ROS), mediated by peptides. The liberation of 
ROS in the cell creates damage and activates endonucleases that cleave DNA, creating an escalating apoptotic effect. ROS disrupt mitochondria, creating a cascade of events that leads the cells to death. This cascade effect seems extremely powerful since peptides from kefir are naturally positively charged, thus being electrochemically attracted by negatively charged components of cancerous cells. EPS contributes to apoptosis of cancerous cells, activating macrophages and T-lymphocyte. Moreover, regulation of genes expression seems to be involved in anti-tumour potential of kefir, as its consumption seems to up-regulate pro-apoptotic systems and down-regulate proliferations systems [75]. In their review, Rafie et al. reported the amount of kefir supplemented for the experiments, ranging from $200 \mu \mathrm{L}$ to $5 \mathrm{~mL}$, but, as all the listed experiments are in vitro on cancerous cells, the precise amount that has to be consumed to reach a positive effect needs to be further investigated [75]. Kefir was administered by Özcan et al. to postmenopausal women to improve quality of sleep and thus reduce mental disorders, like depression and stress accumulation. It is well known that the gut-brain axis is a highway, and what affect the guts, reflects on the brain $[76,77]$. In this sense, the beneficial effect of kefir reducing harmful microflora, improving motility, and modulating immune function helps to reduce sleeps disorders, depression, stress, and anxiety, thus increasing the quality of life. In this study, patients were supplemented with $500 \mathrm{~mL}$ of kefir daily, to drink half in the morning and the rest in the evening. The ingested amount is considerably high, but it has to be taken into account that the experiments were conducted in Turkey, where kefir consumption is traditionally rooted in the population [78]. Kefir was administered also to ovariectomized mice to study the effect of kefir's peptide fraction on estrogenic deficiency-induced osteoporosis and evaluate in model systems prevention of menopausal osteoporosis. As already stated, in fact, kefir can modulate gut microbiota through different patterns, influencing many aspects of physiological processes like absorption of nutrients, hormone regulation, and metabolic processes. Moreover, through EPS of kefiran, kefir exerts a bifidogenic effect, increasing sensibly the amount Bifidobacterium in the guts, reducing the amount of pathogenic microflora (fungi, protozoa, viruses, and bacteria), due to the production of organic acids and bioactive peptides [79]. Modulation on the hosts exerted by kefir is also broadened by the promotion of fatty acids oxidation by increasing Lactobacillaceae population as well as Kluyveromyces spp. presence in the gut [72]. Kefir containing a natural probiotic, able to release SCFA in the media and the guts, contributes to bone formation and improves bone density [80]. Different studies focused on this topic both in animal and humans, confirming the effect of kefir in reducing bone loss, increasing bone density and elastic moduli of bones, and preventing fractures that may result in fatal ending for elderly persons. This effect is enhanced when combined with calcium-carbonate supplementation [81-83]. In the end, being so widespread, easy to use, and obtain, kefir looks like a treasure chest of positive effects for consumers.

\subsubsection{Cheese}

Cheese is an umbrella term under which many products differentiated by production techniques, composition, environment, and microbial evolution find space. The combination of productive processes and microbiota are fundamental to differentiate products. For example, during fast ripening, the amount of lactose is reduced by microorganisms, leaving a reduced amount of lactose final product, making these cheeses a choice for lactose-sensitive individuals. On the other hand, during prolonged ripening, which can last for months and even years, lactose is completely consumed by LAB, making these cheeses an attractive source of dairy micro- and macro-nutrients for lactose-intolerant people. During the first stages of fermentation, bacteria consume carbohydrates, leaving just a fraction of indigestible oligosaccharides in the matrix that is proven to reach the intestine and exert prebiotics effect, stimulating positive microflora [84,85]. During early stages of ripening, lactose is rapidly degraded in lactate, by means of starter LAB. Lactate can then be metabolized by Propionibacterium, Clostridia, and Pediococci in propionate, butyrate, and formic acid, respectively [86]. Milk contains also citrate that is normally involved in LAB metabolism by citrate positive bacteria, mainly Lactococci [86]. Strains 
usually involved are Lactobacillus lactis ssp. lactis biovar diacetylactis, and Leuconostoc mesenteroides, which produce acetate, diacetyl, 2-butanone, and 2,3-butanediol [86]. Another important metabolism of LAB during ripening is proteolysis, resulting in the release in the matrix of branched-chain amino acids such as leucine, iso leucine, and valine; aromatic amino acids such as tryptophan, phenylalanine, and tyrosine; and sulfur-containing amino acid such as methionine. Peptides and ammino acids in cheese are often in an interesting bioavailable form [86]. During ripening time, small peptides are released by the action of enzymes, residual rennet activity, and LAB. A part of these peptides can be metabolized by LAB [87], and is well known for bioactivities, such as opioids, ACE-inhibitors, and immuno-stimulating activities. Some other peptides vehiculate minerals to the intestine and peripheric organs via blood transport [88]. There is an expanding body of evidence concerning a negative correlation between intake of dairy products and development of hypertension [89]. This anti-hypertensive effect seems to be correlated to the presence of calcium and small peptides with ACE-inhibitors activity, like IPP or VPP peptides [90,91]. Ripening of cheese is positively correlated with these bioactive peptides, which are normally present in cryptic form inside caseins. In a double-blind study, Crippa et al. fed Grana Padano, a long ripened Italian cheese, to 30 patients with hypertension issues and reported a significant decrease in systolic and diastolic blood pressure after 2 months of administration of 35 grams of grated cheese per day. The decrease of blood pressure was in the order of $-4.8 / 3.5 \mathrm{mmHg}$, which is interesting considering that a reduction of 3 $\mathrm{mmHg}$ can reduce the risk of heart attack and failure of about 13\% [92]. In recent years, cheese-isolated probiotics have gained attention due to their ability to produce a variety of bioactive compounds like SCFA from the fermentation of non-digestible carbohydrates [93]; their antimicrobial effect towards pathogenic microflora; as well as their ability to improve immune response, reduce serum cholesterol level, and alleviate diarrheic symptoms [94]. Recently, literature focused on compounds with the ability to modulate mood [95,96]. One of the most studied mood-modulators is $\gamma$-aminobutyric acid (GABA). GABA is a non-protein amino acid derived from decarboxylation of glutamate [87] and is one of the main inhibitory neurotransmitters in the central nervous system of mammalians. Studies showed its involvement in managing stress, influencing behaviour and personality, and hypotensive and anti-diabetic properties [95,97]. Moreover, its effect was also noticed in preventing depression and helping in the treatment of alcoholism by activating specific receptors and increasing lymphocyte counts [87]. Strains able to produce GABA during fermentation of milk are Lacticaseibacillus paracasei, Lentilactobacillus buchneri, L. delbrueckii subsp. bulgaricus, Lactiplantibacillus plantarum, Levilactobacillus brevis, Lacticaseibacillus rhamnosus, and Lactococcus lactis $[95,98]$. Cheese seems to exert a protective effect towards these bacteria, due to the high fat content that protects bacteria and allows them to reach the intestine, where they can exert multiple positive effects [98]. Knowing this, the introduction of cheese, especially long ripened ones in the diet, allows the introduction of numerous positive compounds like bioactive peptides, minerals, liposoluble vitamins, organic acids, and other antimicrobial compounds, together with a positive and stress-resistant microflora (Table 2). Moreover, cheese can convey mood modulators to the hosts, helping in the management of stress and altered mood states. 
Table 2. Health-related effects of fermented dairy products.

\begin{tabular}{|c|c|c|c|c|}
\hline Health Effects & Specific Effects & Fermented Food & Microorganisms & Reference \\
\hline \multirow[t]{2}{*}{$\begin{array}{l}\text { Reduce initiation and progression of } \\
\text { cronic disease: }\end{array}$} & & food ingredients, including living microbial cells & Lactobacillus and Lactococcus genera & [99] \\
\hline & $\begin{array}{l}\text { Musculoskeletal disorders } \\
\text { Cardiovascular diseases } \\
\text { Mental health pathologies } \\
\text { Type } 2 \text { diabetes }\end{array}$ & & & \\
\hline \multirow[t]{2}{*}{ Production of Bioactive peptides: } & & $\begin{array}{l}\text { Milk-derived foods (Fermented milks, Cheese, } \\
\text { yoghurt, kefir) }\end{array}$ & Lactobacillus and Lactococcus genera & [99] \\
\hline & $\begin{array}{c}\text { Satiety regulation } \\
\text { Antimicrobial } \\
\text { Anti-carcinogenic } \\
\text { Anti-thrombotic } \\
\text { Mineral absorption } \\
\text { Hypotensive } \\
\text { Anti-inflammatory } \\
\text { Stress relief } \\
\text { Aids relaxation and sleep } \\
\text { Reduces symptoms of psoriasis } \\
\text { ACE-inhibitors }\end{array}$ & & & \\
\hline Amelioration of glucose metabolism & & LAB-fermented foods, especially fermented milks & GRAS Lactic acid bacteria & [100] \\
\hline $\begin{array}{c}\text { Amelioration of glucose intollerance } \\
\text { symptoms }\end{array}$ & & LAB-fermented foods, especially fermented milks & GRAS Lactic acid bacteria & [100] \\
\hline Reduce severity of infections & & LAB-fermented foods, especially fermented milks & GRAS Lactic acid bacteria & [100] \\
\hline Reduce burden of IBS & & LAB-fermented foods, especially fermented milks & GRAS Lactic acid bacteria & [100] \\
\hline Anti-anxiety effect & & LAB-fermented foods, especially fermented milks & GRAS Lactic acid bacteria & [100] \\
\hline Reduction of serum cholesterol level & & & & [101] \\
\hline Production of B's group vitamines & & Fermented milks, Yoghurts, Fermented Soymilk, Kefir & $\begin{array}{l}\text { L. casei, Bifidobacterium infantis, } L . \\
\text { plantarum... }\end{array}$ & [101] \\
\hline \multirow[t]{2}{*}{ Production of GABA } & & & & [101] \\
\hline & Antidiabetic, blood pressure & Fermented milk, Fermented soy milk, Yoghurt & $\begin{array}{l}\text { L. casei Shirota, S. salivarius, L. } \\
\text { plantarum, L. brevis }\end{array}$ & \\
\hline
\end{tabular}


Table 2. Cont.

\begin{tabular}{|c|c|c|c|c|}
\hline Health Effects & Specific Effects & Fermented Food & Microorganisms & Reference \\
\hline \multirow[t]{2}{*}{$\begin{array}{l}\text { Production of conjugated linoleic } \\
\text { acid }\end{array}$} & & & & [101] \\
\hline & Cholesterol lowering & $\begin{array}{c}\text { Cheddar cheese, Buffalo cheese, Fermented buffalo } \\
\text { milk, Yoghurt }\end{array}$ & $\begin{array}{l}\text { L. lactis, L. rhamnosus, S. } \\
\text { thermophilus, B. bifidum }\end{array}$ & [101] \\
\hline \multirow[t]{3}{*}{ Exopolysaccharides production } & & & & [101] \\
\hline & Immunostimulatory & $\begin{array}{c}\text { Yoghurt, Cheddar cheese, Turkish cheese, Kefir, } \\
\text { Fermented ice-cream }\end{array}$ & $\begin{array}{l}\text { L. bulgaricus, L. mucosae, } P \text {. } \\
\text { freudenreichii, L. lactis, B. longum }\end{array}$ & \\
\hline & $\begin{array}{l}\text { Hypocholesterolemic } \\
\text { Microbiota modulation } \\
\text { Immune modulation }\end{array}$ & & & \\
\hline \multicolumn{2}{|l|}{ Bacteriocines production } & $\begin{array}{l}\text { Camembert/Semihard cheese, Cheddar, Yoghurt, } \\
\text { Munster cheese }\end{array}$ & L. lactis, L. acidophilus, P. acidilactici & [101] \\
\hline \multicolumn{2}{|l|}{ Alleviate constipation } & Yoghurt & $\begin{array}{l}\text { B. animalis subsp lactis DN-173010, L. } \\
\text { casei subsp Shirota }\end{array}$ & [102] \\
\hline \multicolumn{2}{|l|}{ Reduce eczemas } & fermented milk & & [102] \\
\hline \multirow{2}{*}{\multicolumn{2}{|c|}{$\begin{array}{l}\text { Antibiotic-associated diarrhea } \\
\text { Prevention of pediatric diarrhea } \\
\text { Prevention and help healing from respiratory infections }\end{array}$}} & Fermented drink, yoghurt & Lactobacillus casei DN-114001 & [102] \\
\hline & & Fermented drink, yoghurt & Lactobacillus casei DN-114003 & [102] \\
\hline \multirow[t]{3}{*}{ Fights infections } & & & & [102] \\
\hline & H. pylori infection & Fermented oat gruel in fruit drink & L. plantarum 299v (DSM9843) & \\
\hline & Clostridium difficile infection & Fermented drink & $\begin{array}{l}\text { L. acidophilus CL1285 + L. casei } \\
\text { Lbc80r + L. rhamnosus CLR2 }\end{array}$ & \\
\hline \multicolumn{2}{|l|}{ Improves microbiota } & Yoghurt & $\begin{array}{c}\text { L. acidophilus }+ \text { B. animalis subsp } \\
\text { lactis }\end{array}$ & [102] \\
\hline
\end{tabular}




\subsection{Vegetable Fermented Products}

Since ancient times, the fermentation of vegetables has also been practiced by mankind, as proved by a long history of traditional products spread all over the world. Vegetables are mainly fermented by LAB both spontaneously and by means of inoculum and backslopping $[103,104]$. Among these lacto-fermented vegetables are fermented cabbage (kimchi and sauerkrauts), fermented leaf (gundruk) and pickles (cucumber, chillies, capers and others). Many of the positive features related to fermented vegetables are derived from the effects of acids and fermentation, which, as a consequence of fermentation, change their form to become more bioavailable, thus increasing their effect and elimination of anti-nutritional compounds [105]. In this review, we focus on the two main products derived from cabbage fermentation, representing a widely consumed staple in western and eastern areas of the world: sauerkrauts and kimchi. Fermentation of vegetables has as primary effect of increasing the shelf-life of food. Moreover, it allows to ameliorate the intake of nutrients like fiber, vitamins, and minerals. This effect is particularly useful since it permits the introduction of these micronutrients in periods when vegetables are unavailable. In a recent review, Bousquet et al. tried to find a relation between decease due to COVID-19 and diet of populations, focusing on the consumption of sauerkrauts. From their data analysis emerged how in the areas where the consumption of sauerkrauts is higher the number of deaths is slightly lower. Data anyway do not seem to be correlated and many other factors and bias contribute to the obtained results, thus further studies are needed to confirm any link [106].

\subsubsection{Sauerkraut}

Sauerkrauts are the product of cabbage fermentation (Brassica oleracea var. capitata). Sauerkraut manufacturing can be carried out following spontaneous fermentation or fermentations guided by selected and specific bacteria [107]. During fermentation, the composition of the product changes and, at the end, aside from macronutrients, it is possible to find a good amount of fiber, vitamin C, organic acids (lactic, acetic, malic and succinic), SCFA (propionic acid), ethanol, and acetaldehyde. Due to the knowledge about bioactive compounds present in fermented foods, in recent years, many efforts were made to improve the general quality of fermented vegetables while creating a product rich in bioactive compounds. For example, the utilization of a nisin-resistant strain of Leuconostoc mesenteroides in combination with a nisin-producer strain of L. lactis allowed obtaining a product with a suppressed native microflora [107]. Also, Leu. mesenteroides in combination with Pediococus dextrinicus showed a good potentiality to produce bioactive enriched foods. Latilactobacillus sakei showed a predominance in this feature since its utilization in vegetable fermentations allows the obtaining of foods with three times the concentration of bioactive compounds concerning any other studied bacterial strains [107]. Standardization of the product is of course a feature researched by companies. Despite this effort to standardize the products, aiming to use only selected microorganisms, it has to be considered that a reduced microflora diversity could lead to products with decreased bioactivities and a lower release of post- and para-probiotics in the final product [108-110]. Thus, aiming to obtain a safe and health-contributing product, it is important not to underestimate the potential contribution of the autochthonous microflora in the fermentation process [111]. Since many reports suggest that regular consumption of this product can lead to the intake of a considerable amount of healthy bacteria $\left(>10^{6} \log \mathrm{CFU} / \mathrm{g}\right)$, recent studies have focused their attention on the isolation of LAB from sauerkrauts. Strains of Lactiplantibacillus paraplantarum, L. brevis, and others Lactobacillus strains isolated from sauerkrauts showed adhesion to Caco-2-cells and inhibitory activity towards pathogenic microorganisms [107]. Nielsen et al. [112] reported that the effect of sauerkraut consumption on irritable bowel syndrome (IBS) affected a patient and reported that consumption of sauerkrauts, both fresh and pasteurized, led to a reduction of symptoms after 6 weeks, with a change in microbial composition of faecal matters of participants. Also, the high presence of dietary fibers seems to be involved in alleviating IBS symptoms [112]. Cabbages are also rich in phytochemicals 
with multiple possible bioactivities, but these compounds, mainly glucosinolates, are normally not bioavailable in the fresh product. Hydrolysis of glucosinolates leads to release of isothiocyanates, thiocyanates, epithionitriles, nitriles, and indolic compounds, all recognized for their valuable health boosting activities. Like many other fermented foods, sauerkrauts show antitumoral properties, exerted by activating enzymes that eliminate xenobiotics and increasing apoptosis of cancerous cells [107]. Specifically, indole-3-carbinol (I3C) is deeply investigated since it was shown to exert inflammation-modulating effects, promote cells proliferation, and inhibit tumour invasion in different tissues [107]. The presence of vitamins and organic acids gives to sauerkraut a powerful antioxidant feature, but it is also related to reduced inflammation, atherothrombosis, and increased human system efficiency in neutralizing reactive oxygen species. Antioxidant activities are also connected to reduced oxidative damage at the expense of DNA, which can also be due to indolic compounds' ability to scavenge chemicals, avoiding damages to DNA and other structures $[113,114]$. Fermentation enriches sauerkraut with a group of enzymes called Mono Ammino Oxidase Inhibitors (MAOIs), inhibiting Mono Ammino Oxidase (MAOs), which are a family of enzymes involved in arising depressive states, anxiety, obsessivecompulsive disorder, and development of Parkinson's disease [115]. The administration of sauerkraut was also studied in fighting IBS. In a pilot study, Nielsen et al. fed 34 volunteers with pasteurized and unpasteurized sauerkraut to evaluate the reduction in abdominal discomfort and problematics bound to IBS. From the results, it emerged that administration for 6 weeks of unpasteurized sauerkraut and 8 weeks of pasteurized sauerkraut can sensibly reduce abdominal discomfort and negative effects of IBS. Despite the difference in number of live bacteria, this similarity in results can be due to the natural composition of sauerkrauts, rich in glucosinolates and complex carbohydrates, acting as fiber in the intestine. In this optic, fermentation of sauerkrauts leading to glucosinolates breakdown can increase the bioactivity of this fermented food. Also, cells breakdown and liberation in para-probiotics media can contribute to the health-related positive effects of fermented cabbages [112]. Further experiments in this field should consider unpasteurized cabbage to estimate precisely the effect of fermentation with respect to unfermented product [116]. When talking about sauerkraut, many sources refer to its potentiality as a source of fiber and healthy compounds, forgetting about the presence of an abundant and vital LAB microbiota, mainly deriving from spontaneous fermentations that select microorganisms with an increasingly harsh environment. These bacteria have increased possibilities to reach the gut and colonize intestine walls, where they can exert positive effects modulating the microbiota and immune response. As mentioned above, during recent years, literature has explored the idea that microorganisms' viability is not mandatory to exert probiotic effects. Cell wall material, cytosol compounds, and genetic information released after cells death are enough to vehiculate positive features. In this new post- and para-biotic field, sauerkraut has found a niche, since industrial productions require a pasteurization step, resulting in the death of live cells but not hampering the beneficial effects of wild LAB. Sauerkrauts are one of the most studied fermented vegetables, in fact suggestions about the introduction of sauerkraut in the diet are easy to find in the literature, even though intervention studies and dietary supplementation with this fermented food are still lacking and further investigation is surely needed. The literature reveals that sauerkraut possess a vast array of health effects related to glucosinolate compounds and microbial contribution in terms of microbiome, para-, and post-biotics. Despite esethese incredibly appealing features, there is a possible presence of biogenic ammines [117], while paying attention to microbial populations, since some harmful bacteria can survive to harsh conditions that arise during fermentation.

\subsubsection{Kimchi}

Kimchi is the most produced and consumed lacto-fermented vegetable of Korea and its national product. It is often made by natural fermentation of Napa cabbage and other ingredients like onion, garlic, chillies, and fish sauce; their addition is fundamental in 
helping to control pathogenic and harmful microorganisms, allowing the growth of the beneficial ones. It is mainly Leu. mesenteroides that creates the acidic and anaerobic environment adaptable to the growth of more acid-resistant bacteria like L. brevis and L. plantarum. Kimchi is considered a natural functional food for the high presence of dietary fibers, minerals, vitamins, capsaicin, organic acids, polyphenols, and fermentation by-products (organic acids, bacteriocins, and others). The presence of these compounds is reported in scientific literature to produce positive effects on the health of consumers. Presence of a wild and acid-resistant microbiota is connected to the lowering of $\mathrm{pH}$ in the intestinal lumen and in the faeces, which is connected to a better microbiota, with an increased count in LAB and Bifidobacteria and a lower level of harmful and pathogenic microorganisms. Kimchi is studied, especially in the most recent literature, for its ability to modulate gut microflora, and Park et al. studied the effect of kimchi to exert an anti-obesogenic effect on the microbiome, starting from the assumption that many factors can cause obesity, such as an unbalanced diet; genetic factors; and unhealthy gut microflora resulting in modifying energy intake and accumulation in the adipocytes, increasing obesogenic effect [118]. The intestinal microbiota is more than the sum of its part, it is an organism able to live in symbiosis between the same parts composing it and ourselves. Due to microbial diversity, long-term stability, ease of use, and domestic preparation, kimchi was taken into account to modify gut microbiota [117], helping pathologically obese subjects, normalizing their lipid levels and modulating their microbiome [119-121]. Results of these experiments highlighted that supplementation with kimchi in mice fed with an HFD cannot significantly decrease weight gain, with respect to mice fed with just an HFD, indicating that the number of calories introduced is the main factor in weight gain [118]. The introduction of kimchi anyway showed a reduction in blood glucose, triglycerides, and high- and low-density lipoproteins with respect to mice fed with only HFD [122]. Even if the total weight gain was not significantly decreased by kimchi in HFD mice, other indexes like total body fat gain, liver weight, and adipocytes' dimensions and counts were lowered by the administration of kimchi. Also, gut microflora resulted modulated by the administration of kimchi, Akkermansiaceae, Coriobacteriaceae, and Erysipelotrichaceae, which are normally related to HFD and consequently to obese subjects, were lowered in mice fed with kimchi, while the abundance of Muribaculaceae, negatively correlated with obesity, increased in kimchi-fed mice [118]. Kimchi, due to the high presence of fibers and nutritional compounds was also studied as a solution to cope with prediabetics patients [123]. Prediabetics are subjects who have blood glucose higher than unaffected subjects, but not high enough to be considered properly diabetics, and are strongly subject to develop this issue later, due to unhealthy lifestyle and diet [123]. Fortunately, a change in dietary and lifestyle habits can slow, and in some case even stop, the progression of prediabetes into diabetes. In an intervention study, An et al. administered 100 grams of kimchi per meal to 21 prediabetic volunteers for 2 weeks, followed by a 4-week washout period. From anthropometric parameters after regular consumption of kimchi, it emerged that insulin sensitivity and resistance and blood pressure were positively affected by introduction of this fermented product. Also, the participants' body mass index (BMI) and weight decreased significatively, together with waist circumference, which is strongly bound to insulin resistance. The consumption of kimchi thus revealed to be a strong ally in fighting the onset of diabetes [123,124]. Being rich in anti-microbial compounds, produced mainly by an active and resistant positive microflora, kimchi is employed from centuries as "medicine" food and can be ascribed in the functional foods group. Functional foods are "foods or dietary components that may provide a health benefit beyond basic nutrition" [125]. Some studies focused on the utilization of kimchi to fight infections by Helicobacter pylori, which is a well-known contributor to the development of peptic and perforative ulcers and one of the recognized class I carcinogens $[124,126]$. The high level of antioxidants, vitamins, and the presence of other phytochemicals, together with the reduction of ingestion of other harmful products prove to be an effective, cheap, and easy way to control the development of H. pylori and help eradicate it. During H. pylori infection, the body reacts by increasing the expression of 
pro-inflammatory genes to fight the attack, but the maintenance of an inflammation state for too long in the body can lead to DNA damage through oxidative stress and disruption of cell life cycle. In this way, gastric and intestinal carcinogenesis is facilitated. Therefore, the introduction into the diet of a food possessing antioxidant and anti-inflammatory properties such as kimchi results as being useful. In the optic of cancer's prevention, kimchi has been employed as a tool to fight the development of colon-rectal colitis-associated cancer in patients chronically affected with IBS. From the experiments led by Han et al., it emerged that a special formulation of kimchi supplemented to mice, containing pear extracts and see tangle juice, prevents cancer formation by means of inflammasome reduction [127], resulting in anti-inflammatory and anti-oxidant effects, cytoprotective ability, and reduced proliferation of harmful microorganisms due to induction of apoptosis. In the same experiments, it emerged that the introduction of unfermented kimchi does not exert the same protective effect, accelerating the formation of cancers in the gut instead. This highlighted once more that the development of the native microbiota of the vegetable represents the real game changer in health-related effects of fermented foods [127]. Ordinarily, to cope with inflammation and ulcers, anti-inflammatory drugs are prescribed, and this can lead to resistance phenomena and to reduction of positive microbiota sensitive to drugs. Ingestion of kimchi could be a strong ally, due to ease of use, stability, and of course due to the introduction of a series of nutritional compounds exerting a plethora of positive health-related effects. Kimchi can play an important role also in maintaining under control the degeneration of several chronic diseases like IBS, Crohn's disease, and infections due to external attacks or unhealthy eating habits [128-130]. However, it has to be considered that, as for other spontaneous fermented foods, kimchi contains a high level of salt involved in the formulation to control negative microflora. In some studies, the kimchi's supplementation was in fact limited to around $100 \mathrm{~g}$ of fermented food [123], matching nutritional suggestions for salt introduction to the diet, while other studies increased to $210 \mathrm{~g}$ per day the administration of kimchi, which provides a salt content higher than what the guidelines suggest [131]. All this considered, the introduction of kimchi as a regular meal or side-dish also in Western countries could help populations to control the development of gastro-intestinal issues (Table 3). 
Table 3. Health-related effects of fermented vegetables products.

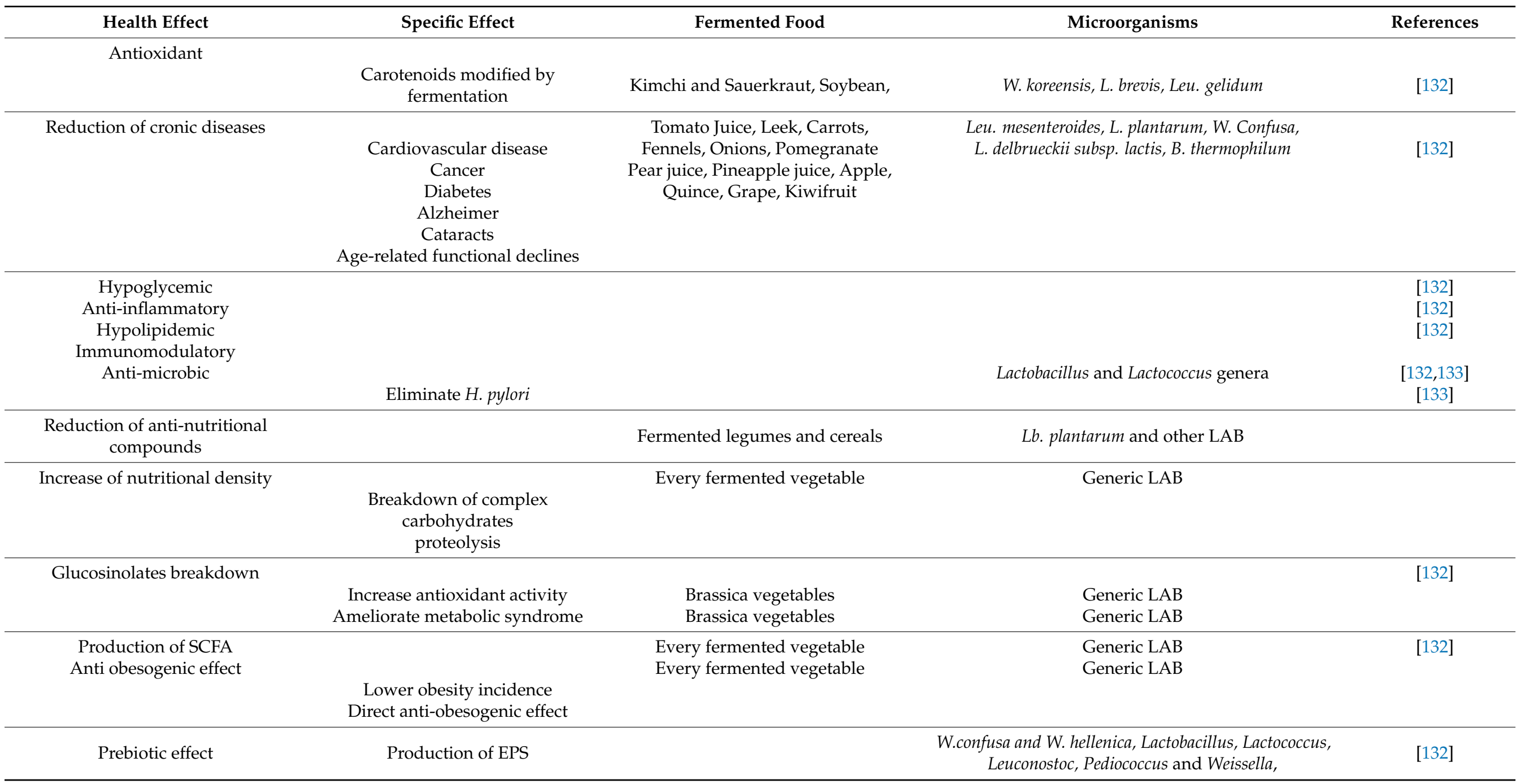




\section{Conclusions}

The aim of this review was to highlight the ability of LAB involved in food's fermentation to exert beneficial effects on human health. Regular ingestion of foods fermented by LAB in the diet can be a great help, due to the introduction of bioactive compounds that are released during fermentation and become available during digestion. It is well established that the ingestion of LAB-fermented foods can modulate the gut microbiome in its functionality and response to stress and attacks, both due to the presence of healthrelated LAB species and their metabolites produced during fermentation. LAB's ability to produce bioactive peptides, vitamins, organic acids, bacteriocins, signalling molecules $(\mathrm{NO})$, and antimicrobial compounds $\left(\mathrm{H}_{2} \mathrm{O}_{2}\right)$ plays a fundamental role in promoting and maintaining a health status in consumers of LAB-fermented products. Despite the need of a higher amount of in vivo studies on a wider population and considering also the possible interaction among different fermented foods contemporaneously introduced, the pieces of evidence reported in the literature so far suggest that higher ingestion of LAB-fermented foods in the diet, daily, could contribute to a healthy lifestyle and in the maintenance of organisms functions and health.

Author Contributions: Conceptualization, V.C. and B.B.; writing-original draft preparation, V.C.; writing-review and editing, B.B., E.B., J.R., M.G. and E.N.; supervision, B.B. All authors have read and agreed to the published version of the manuscript.

Funding: This research received no external funding.

Institutional Review Board Statement: Not applicable.

Informed Consent Statement: Not applicable.

Data Availability Statement: Not applicable.

Conflicts of Interest: The authors declare no conflict of interest.

\section{References}

1. Varzakas, T. Microbiology of Fermented Foods and Beverages. Foods 2020, 9, 1660. [CrossRef] [PubMed]

2. Axelsson, L. Lactic Acid Bacteria: Classific ation and Physiology. In Lactic Acid Bacteria Microbiological and Functional Aspects; Salmine, S., Von Wright, A., Ouwehand, A., Eds.; Marcel Dekker, Inc.: New York, NY, USA, 2004; pp. 195-196. ISBN 0-8247-5332-1.

3. Schillinger, U.; Holzapfel, W. Lactic acid bacteria. In Food Spoilage Microorganisms; de W Blackburn, C., Ed.; Woodhead Publishing Limited: Cambridge, UK, 2006; pp. 541-567. ISBN 978-1-85573-966-6.

4. Narvhus, J.A.; Axelsson, L. Lactic acid bacteria. In Encyclopedia of Food Sciences and Nutrition; Caballero, B., Ed.; Academic Press: Cambridge, MA, USA, 2003; pp. 3465-3472.

5. Bao, Y.; Wang, Z.; Zhang, Y.; Zhang, J.; Wang, L.; Dong, X.; Su, F.; Yao, G.; Wang, S.; Zhang, H. Effect of Lactobacillus plantarum P-8 on lipid metabolism in hyperlipidemic rat model. Eur. J. Lipid Sci. Technol. 2012, 114, 1230-1236. [CrossRef]

6. Liceaga, A.M. Postbiotics and paraprobiotics: From concepts to applications. Food Res. Int. 2020, 136, 109502. [CrossRef]

7. Orisakwe, O.E.; Amadi, C.N.; Frazzoli, C.; Dokubo, A. Nigerian foods of probiotics relevance and chronic metal exposure: A systematic review. Environ. Sci. Pollut. Res. 2020, 27, 19285-19297. [CrossRef] [PubMed]

8. Langella, P.; Guarner, F.; Martín, R. Editorial: Next-generation probiotics: From commensal bacteria to novel drugs and food supplements. Front. Microbiol. 2019, 10, 1973. [CrossRef]

9. Ljungh, Å.; Wadström, T. Lactic Acid Bacteria as Probiotics. Curr. Issues Intest. Microbiol. 2006, 7, 73-90.

10. Vizoso Pinto, M.G.; Franz, C.M.A.P.; Schillinger, U.; Holzapfel, W.H. Lactobacillus spp. with in vitro probiotic properties from human faeces and traditional fermented products. Int. J. Food Microbiol. 2006, 109, 205-214. [CrossRef]

11. Martín, R.; Langella, P. Emerging health concepts in the probiotics field: Streamlining the definitions. Front. Microbiol. 2019, 10, 1047. [CrossRef]

12. Lin, T.L.; Shu, C.C.; Lai, W.F.; Tzeng, C.M.; Lai, H.C.; Lu, C.C. Investiture of next generation probiotics on amelioration of diseases-Strains do matter. Med. Microecol. 2019, 1-2, 100002. [CrossRef]

13. Sagheddu, V.; Guidesi, E.; Galletti, S.; Elli, M. Selection and Characterization Criteria of Probiotics Intended for Human Use from the Past to the Future. Food Sci. Nutr. Stud. 2019, 3, 73. [CrossRef]

14. Suez, J.; Zmora, N.; Elinav, E. Probiotics in the next-generation sequencing era. Gut Microbes 2020, 11, 77-93. [CrossRef] [PubMed]

15. van Pijkeren, J.-P.; Barrangou, R. Genome Editing of Food-Grade Lactobacilli to Develop Therapeutic Probiotics. Microbiol. Spectr. 2017, 5. [CrossRef]

16. Morovic, W.; Budinoff, C.R. Epigenetics: A New Frontier in Probiotic Research. Trends Microbiol. 2021, 29, 117-126. [CrossRef] 
17. O'Toole, P.W.; Marchesi, J.R.; Hill, C. Next-generation probiotics: The spectrum from probiotics to live biotherapeutics. Nat. Microbiol. 2017, 2, 17057. [CrossRef]

18. Peredo-Lovillo, A.; Romero-Luna, H.E.; Jiménez-Fernández, M. Health promoting microbial metabolites produced by gut microbiota after prebiotics metabolism. Food Res. Int. 2020, 136, 109473. [CrossRef] [PubMed]

19. FAO/WHO. Guidelines for the Evaluation of Probiotics in Food. 2002, pp. 1-11. Available online: https://www.who.int/ foodsafety/fs_management/en/probiotic_guidelines.pdf (accessed on 10 August 2021).

20. Conte, M.; Porpora, M.; Nigro, F.; Nigro, R.; Budelli, A.L.; Barone, M.V.; Nanayakkara, M. Pro-Pre and Postbiotic in Celiac Disease. Appl. Sci. 2021, 11, 8185. [CrossRef]

21. Sugawara, T.; Sawada, D.; Ishida, Y.; Aihara, K.; Aoki, Y.; Takehara, I.; Takano, K.; Fujiwara, S. Regulatory effect of paraprobiotic Lactobacillus gasseri CP2305 on gut environment and function. Microb. Ecol. Health Dis. 2016, 27, 30259. [CrossRef] [PubMed]

22. Średnicka, P.; Juszczuk-Kubiak, E.; Wójcicki, M.; Akimowicz, M.; Roszko, M. Probiotics as a biological detoxification tool of food chemical contamination: A review. Food Chem. Toxicol. 2021, 153, 112306. [CrossRef]

23. Rau, M.; Rehman, A.; Dittrich, M.; Groen, A.K.; Hermanns, H.M.; Seyfried, F.; Beyersdorf, N.; Dandekar, T.; Rosenstiel, P.; Geier, A. Fecal SCFAs and SCFA-producing bacteria in gut microbiome of human NAFLD as a putative link to systemic T-cell activation and advanced disease. United Eur. Gastroenterol. J. 2018, 6, 1496-1507. [CrossRef]

24. den Besten, G.; Lange, K.; Havinga, R.; van Dijk, T.H.; Gerding, A.; van Eunen, K.; Müller, M.; Groen, A.K.; Hooiveld, G.J.; Bakker, B.M.; et al. Gut-derived short-chain fatty acids are vividly assimilated into host carbohydrates and lipids. Am. J. Physiol.-Gastrointest. Liver Physiol. 2013, 305, 900-910. [CrossRef] [PubMed]

25. Hernández, M.A.G.; Canfora, E.E.; Jocken, J.W.E.; Blaak, E.E. The short-chain fatty acid acetate in body weight control and insulin sensitivity. Nutrients 2019, 11, 1943. [CrossRef]

26. Marco, M.L.; Heeney, D.; Binda, S.; Cifelli, C.J.; Cotter, P.D.; Foligné, B.; Gänzle, M.; Kort, R.; Pasin, G.; Pihlanto, A.; et al. Health benefits of fermented foods: Microbiota and beyond. Curr. Opin. Biotechnol. 2017, 44, 94-102. [CrossRef] [PubMed]

27. Dimidi, E.; Cox, S.; Rossi, M.; Whelan, K. Fermented foods: Definitions and characteristics, impact on the gut microbiota and effects on gastrointestinal health and disease. Nutrients 2019, 11, 1806. [CrossRef] [PubMed]

28. Gille, D.; Schmid, A.; Walther, B.; Vergères, G. Fermented food and non-communicable chronic diseases: A review. Nutrients 2018, 10, 448. [CrossRef] [PubMed]

29. Şanlier, N.; Gökcen, B.B.; Sezgin, A.C. Health benefits of fermented foods. Crit. Rev. Food Sci. Nutr. 2019, 59, 506-527. [CrossRef] [PubMed]

30. La Fata, G.; Weber, P.; Mohajeri, M.H. Probiotics and the Gut Immune System: Indirect Regulation. Probiotics Antimicrob. Proteins 2018, 10, 11-21. [CrossRef]

31. Qi, D.; Nie, X.L.; Zhang, J.J. The effect of probiotics supplementation on blood pressure: A systemic review and meta-analysis. Lipids Health Dis. 2020, 19, 1-11. [CrossRef] [PubMed]

32. Hao, X.; Yang, W.; Zhu, Q.; Zhang, G.; Zhang, X.; Liu, L.; Li, X.; Hussain, M.; Ni, C.; Jiang, X. Proteolysis and ACE-inhibitory peptide profile of Cheddar cheese: Effect of digestion treatment and different probiotics. LWT 2021, 145, 111295. [CrossRef]

33. Korcz, E.; Varga, L. Exopolysaccharides from lactic acid bacteria: Techno-functional application in the food industry. Trends Food Sci. Technol. 2021, 110, 375-384. [CrossRef]

34. Hidalgo-Cantabrana, C.; López, P.; Gueimonde, M.; de los Reyes-Gavilán, C.G.; Suárez, A.; Margolles, A.; Ruas-Madiedo, P. Immune Modulation Capability of Exopolysaccharides Synthesised by Lactic Acid Bacteria and Bifidobacteria. Probiotics Antimicrob. Proteins 2012, 4, 227-237. [CrossRef]

35. Lynch, K.M.; Zannini, E.; Coffey, A.; Arendt, E.K. Lactic Acid Bacteria Exopolysaccharides in Foods and Beverages: Isolation, Properties, Characterization, and Health Benefits. Annu. Rev. Food Sci. Technol. 2018, 9, 155-176. [CrossRef]

36. Holst, O.; Brennan, J.P.; Von Itzstein, M. Microbial Glycobiology, 1st ed.; Academic Press: Cambridge, MA, USA, 2009; ISBN 9780123745460 .

37. Yang, H.; He, M.; Wu, C. Cross protection of lactic acid bacteria during environmental stresses: Stress responses and underlying mechanisms. LWT 2021, 144, 111203. [CrossRef]

38. Ren, C.; Dokter-Fokkens, J.; Figueroa Lozano, S.; Zhang, Q.; de Haan, B.J.; Zhang, H.; Faas, M.M.; de Vos, P. Lactic Acid Bacteria May Impact Intestinal Barrier Function by Modulating Goblet Cells. Mol. Nutr. Food Res. 2018, 62, 1700572. [CrossRef]

39. George, F.; Daniel, C.; Thomas, M.; Singer, E.; Guilbaud, A.; Tessier, F.J.; Revol-Junelles, A.M.; Borges, F.; Foligné, B. Occurrence and dynamism of lactic acid bacteria in distinct ecological niches: A multifaceted functional health perspective. Front. Microbiol. 2018, 9, 2899. [CrossRef] [PubMed]

40. Van De Water, J.; Naiyanetr, P. Yoghurt and Immunity: The Health Benefits of Fermented Milk Products that Contain Lactic Acid Bacteria. In Handbook of Fermented Functional Foods; Farnworth, E., Ed.; CRC Press: Boca Raton, FL, USA, 2008; pp. 71-88. ISBN 978-1-4200-5326-5.

41. Kabak, B.; Dobson, A.D.W. An introduction to the traditional fermented foods and beverages of Turkey. Crit. Rev. Food Sci. Nutr. 2011, 51, 248-260. [CrossRef] [PubMed]

42. Ray, R.C.; Montet, D. Microorganisms and Fermentation of Traditional Foods; CRC Press: Boca Raton, FL, USA, 2015; ISBN 9781482223095. 
43. von Gastrow, L.; Madec, M.N.; Chuat, V.; Lubac, S.; Morinière, C.; Lé, S.; Santoni, S.; Sicard, D.; Valence, F. Microbial diversity associated with gwell, a traditional french mesophilic fermented milk inoculated with a natural starter. Microorganisms 2020, 8 , 982. [CrossRef] [PubMed]

44. Li, H.; Wang, Y.; Zhang, T.; Li, J.; Zhou, Y.; Li, H.; Yu, J. Comparison of backslopping and two-stage fermentation methods for koumiss powder production based on chemical composition and nutritional properties. J. Sci. Food Agric. 2020, 100, 1822-1826. [CrossRef]

45. World Health Organization; Food and Agriculture Organization of the United Nations. Codex Alimentarus: Milk and Milk Products; World Health Organization: Geneva, Switzerland; Food and Agriculture Organization of the United Nations: Rome, Italy, 2011; ISBN 9789251058374.

46. Willet, W.C.; Ludwig, D.S. Milk and health. N. Engl. J. Med. 2020, 382, 644-654. [CrossRef] [PubMed]

47. Gómez-Gallego, C.; Gueimonde, M.; Salminen, S. The role of yogurt in food-based dietary guidelines. Nutr. Rev. 2018, 76, 29-39. [CrossRef]

48. Sarkar, S. Potentiality of probiotic yoghurt as a functional food-A review. Nutr. Food Sci. 2019, 49, 182-202. [CrossRef]

49. Korhonen, H. Milk-derived bioactive peptides: From science to applications. J. Funct. Foods 2009, 1, 177-187. [CrossRef]

50. Fernandez, M.A.; Picard-Deland, E.; Le Barz, M.; Daniel, L.; Marette, A. Yoghurt and Health. In Fermented Foods in Health and Disease Prevention; Frias, J., Martinez-Villaluenga, C., Penas, E., Eds.; Academic Press: London, UK, 2017; pp. 305-327. ISBN 978-0-12-802309-9.

51. den Hartigh, L.J. Conjugated linoleic acid effects on cancer, obesity, and atherosclerosis: A review of pre-clinical and human trials with current perspectives. Nutrients 2018, 11,370. [CrossRef]

52. Thavasuraj, S.; Nithya, V. Evaluation on efficacy of fatty acids and Conjugated Linoleic Acid [CLA] derived from indegenous cow milk against hepato cellular carcinoma: A key and novel approach. Biochem. Cell. Arch. 2020, 20, 3253-3257.

53. Thavasuraj, S.; Nithya, V.; Vinotha, M.; Chinniah, S.; Archunan, G. Assessment of dosage response of cow milk fat isomers against hepatocellular carcinoma cell lines: A key to novel approach for anticancer. Biochem. Cell. Arch. 2020, 20, $3223-3227$.

54. Abd El-Gawad, A.M.; Abo El-Hassan, D.G.; Aboul-Enein, A.M.; Abdelgayed, S.S.; Aly, S.A.; Esmat, G.; Mostafa, A.A.; Bakr, M.H.; Ali, R.A.; Ayoub, M.A. Anticancer activity of milk fat rich in conjugated linoleic acid against Ehrlich ascites carcinoma cells in female Swiss albino mice. Vet. World 2021, 14, 696-708. [CrossRef]

55. Kousgaard, S.J.; Nielsen, H.L.; Kirk, K.F.; Thorlacius-Ussing, O. Consumption of yoghurt favours remission after faecal microbiota transplantation for chronic pouchitis. Int. J. Colorectal Dis. 2020, 35, 1955-1958. [CrossRef]

56. Panel, E.; Nda, A.; Golly, I. Scientific Opinion on the substantiation of health claims related to live yoghurt cultures and improved lactose digestion (ID 1143, 2976) pursuant to Article 13(1) of Regulation (EC) No 1924/2006. EFSA J. 2010, 8, 1763. [CrossRef]

57. Barengolts, E.; Smith, E.D.; Reutrakul, S.; Tonucci, L.; Anothaisintawee, T. The effect of probiotic yogurt on glycemic control in type 2 diabetes or obesity: A meta-analysis of nine randomized controlled trials. Nutrients 2019, 11, 671. [CrossRef] [PubMed]

58. Kong, C.Y.; Li, Z.M.; Han, B.; Zhang, Z.Y.; Chen, H.L.; Zhang, S.L.; Xu, J.Q.; Mao, Y.Q.; Zhao, Y.P.; Wang, L.S. Diet Consisting of Balanced Yogurt, Fruit, and Vegetables Modifies the Gut Microbiota and Protects Mice against Nonalcoholic Fatty Liver Disease. Mol. Nutr. Food Res. 2019, 63, 1900249. [CrossRef] [PubMed]

59. Liu, J.; Yu, C.; Li, R.; Liu, K.; Jin, G.; Ge, R.; Tang, F.; Cui, S. High-altitude Tibetan fermented milk ameliorated cognitive dysfunction by modified gut microbiota in Alzheimer's disease transgenic mice. Food Funct. 2020, 11, 5308-5319. [CrossRef]

60. Guo, X.; Long, R.; Kreuzer, M.; Ding, L.; Shang, Z.; Zhang, Y.; Yang, Y.; Cui, G. Importance of Functional Ingredients in Yak Milk-Derived Food on Health of Tibetan Nomads Living Under High-Altitude Stress: A Review. Crit. Rev. Food Sci. Nutr. 2014, 54, 292-302. [CrossRef] [PubMed]

61. Mazidi, M.; Mikhailidis, D.P.; Sattar, N.; Howard, G.; Graham, I.; Banach, M. Consumption of dairy product and its association with total and cause specific mortality-A population-based cohort study and meta-analysis. Clin. Nutr. 2019, 38, 2833-2845. [CrossRef] [PubMed]

62. Guo, J.; Astrup, A.; Lovegrove, J.A.; Gijsbers, L.; Givens, D.I.; Soedamah-Muthu, S.S. Milk and dairy consumption and risk of cardiovascular diseases and all-cause mortality: Dose-response meta-analysis of prospective cohort studies. Eur. J. Epidemiol. 2017, 32, 269-287. [CrossRef]

63. Farvid, M.S.; Malekshah, A.F.; Pourshams, A.; Poustchi, H.; Sepanlou, S.G.; Sharafkhah, M.; Khoshnia, M.; Farvid, M.; Abnet, C.C.; Kamangar, F.; et al. Dairy food intake and all-cause, cardiovascular disease, and cancer mortality: The Golestan Cohort Study. Am. J. Epidemiol. 2017, 185, 697-711. [CrossRef] [PubMed]

64. Rosa, D.D.; Dias, M.M.S.; Grześkowiak, Ł.M.; Reis, S.A.; Conceição, L.L.; Peluzio, M.D.C.G. Milk kefir: Nutritional, microbiological and health benefits. Nutr. Res. Rev. 2017, 30, 82-96. [CrossRef]

65. Azizi, N.F.; Kumar, M.R.; Yeap, S.K.; Abdullah, J.O.; Khalid, M.; Omar, A.R.; Osman, M.A.; Mortadza, S.A.S.; Alitheen, N.B. Kefir and its biological activities. Foods 2021, 10, 1210. [CrossRef]

66. Vinderola, C.G.; Duarte, J.; Thangavel, D.; Perdigón, G.; Farnworth, E.; Matar, C. Immunomodulating capacity of kefir. J. Dairy Res. 2005, 72, 195-202. [CrossRef] [PubMed]

67. Bengoa, A.A.; Iraporda, C.; Garrote, G.L.; Abraham, A.G. Kefir micro-organisms: Their role in grain assembly and health properties of fermented milk. J. Appl. Microbiol. 2019, 126, 686-700. [CrossRef]

68. Kesenkas, H.; Gursoy, O.; Ozbas, H. Kefir. In Fermented Foods in Health and Disease Prevention; Frias, J., Martinez-Villaluenga, C., Penas, E., Eds.; Academic Press: London, UK, 2017; pp. 339-353. ISBN 978-0-12-802309-9. 
69. Talib, N.; Mohamad, N.E.; Yeap, S.K.; Hussin, Y.; Mubin Aziz, M.N.; Masarudin, M.J.; Sharifuddin, S.A.; Hui, Y.W.; Ho, C.L.; Alitheen, N.B. Isolation and characterization of Lactobacillus spp. From kefir samples in Malaysia. Molecules 2019, $24,2606$. [CrossRef]

70. Rodrigues, K.L.; Gaudino Caputo, L.R.; Tavares Carvalho, J.C.; Evangelista, J.; Schneedorf, J.M. Antimicrobial and healing activity of kefir and kefiran extract. Int. J. Antimicrob. Agents 2005, 25, 404-408. [CrossRef]

71. Rosa, D.D.; Grześkowiak, L.M.; Ferreira, C.L.L.F.; Fonseca, A.C.M.; Reis, S.A.; Dias, M.M.; Siqueira, N.P.; Silva, L.L.; Neves, C.A.; Oliveira, L.L.; et al. Kefir reduces insulin resistance and inflammatory cytokine expression in an animal model of metabolic syndrome. Food Funct. 2016, 7, 3390-3401. [CrossRef]

72. Bellikci-Koyu, E.; Sarer-Yurekli, B.P.; Akyon, Y.; Aydin-kose, F.; Karagozlu, C.; Ozgen, A.G.; Brikmann, A.; Nitsche, A.; Ergunay, K.; Yilmaz, E.; et al. Effects of regular kefir consumption on gut microbiota in patients with metabolic syndrome: A parallel-group, randomized, controlled study. Nutrients 2019, 11, 2089. [CrossRef]

73. Kim, D.H.; Kim, H.; Jeong, D.; Kang, I.B.; Chon, J.W.; Kim, H.S.; Song, K.Y.; Seo, K.H. Kefir alleviates obesity and hepatic steatosis in high-fat diet-fed mice by modulation of gut microbiota and mycobiota: Targeted and untargeted community analysis with correlation of biomarkers. J. Nutr. Biochem. 2017, 44, 35-43. [CrossRef]

74. Veiga, F.M.S.; Graus-Nunes, F.; Rachid, T.L.; Barreto, A.B.; Mandarim-de-Lacerda, C.A.; Souza-Mello, V. Anti-obesogenic effects of WY14643 (PPAR-alpha agonist): Hepatic mitochondrial enhancement and suppressed lipogenic pathway in diet-induced obese mice. Biochimie 2017, 140, 106-116. [CrossRef] [PubMed]

75. Sharifi, M.; Moridnia, A.; Mortazavi, D.; Salehi, M.; Bagheri, M.; Sheikhi, A. Kefir A powerful probiotics with anticancer properties. Med. Oncol. 2017, 34, 1-7. [CrossRef] [PubMed]

76. Rafie, N.; Hamedani, S.G.; Ghiasv, R.; Miraghajani, M. Kefir and cancer: A systematic review of literatures. Arch. Iran. Med. 2015, $18,852-857$.

77. Miller, I. The gut-brain axis: Historical reflections. Microb. Ecol. Health Dis. 2018, 29, 1542921. [CrossRef] [PubMed]

78. Kim, N.; Yun, M.; Oh, Y.J.; Choi, H.J. Mind-altering with the gut: Modulation of the gut-brain axis with probiotics. J. Microbiol. 2018, 56, 172-182. [CrossRef] [PubMed]

79. Özcan, H.; Oskay, Ü.; Bodur, A.F. Effects of Kefir on Quality of Life and Sleep Disturbances in Postmenopausal Women. Holist. Nurs. Pract. 2019, 33, 207-213. [CrossRef] [PubMed]

80. Kim, D.H.; Jeong, D.; Kim, H.; Seo, K.H. Modern perspectives on the health benefits of kefir in next generation sequencing era: Improvement of the host gut microbiota. Crit. Rev. Food Sci. Nutr. 2019, 59, 1782-1793. [CrossRef]

81. Behera, J.; Ison, J.; Tyagi, S.C.; Tyagi, N. The role of gut microbiota in bone homeostasis. Bone 2020, 135, 115317. [CrossRef] [PubMed]

82. Tu, M.; Han, K.; Chang, G.R.; Lai, G.; Chang, K.Y.; Lai, J.C.; Lai, C.Y.; Chen, H.L.; Chen, C.M. Kefir Peptides Prevent Estrogen Deficiency-Induced Bone Loss and Modulate the Structure of the Gut Microbiota in Ovariectomized Mice. Nutrients 2020, 12, 3432. [CrossRef] [PubMed]

83. Tu, M.Y.; Chen, H.L.; Tung, Y.T.; Kao, C.C.; Hu, F.C.; Chen, C.M. Short-Term Effects of Kefir-Fermented Milk Consumption on Bone Mineral Density and Bone Metabolism in a Randomized Clinical Trial of Osteoporotic Patients. PLoS ONE 2015, 10, e0144231. [CrossRef] [PubMed]

84. Chen, H.L.; Tung, Y.T.; Chuang, C.H.; Tu, M.Y.; Tsai, T.C.; Chang, S.Y.; Chen, C.M. Kefir improves bone mass and microarchitecture in an ovariectomized rat model of postmenopausal osteoporosis. Osteoporos. Int. 2015, 26, 589-599. [CrossRef] [PubMed]

85. Oliveira, D.L.; Costabile, A.; Wilbey, R.A.; Grandison, A.S.; Duarte, L.C.; Roseiro, L.B. In vitro evaluation of the fermentation properties and potential prebiotic activity of caprine cheese whey oligosaccharides in batch culture systems. BioFactors 2012, 38, 440-449. [CrossRef]

86. Vera, C.; Illanes, A. Lactose-Derived Nondigestible Oligosaccharides and Other High Added-Value Products. In Lactose: Structure, Food Industry Applications and Role in Disorders; Illanes, A., Guerrero, C., Vera, C., Wilson, L., Conejeros, R., Scott, F., Eds.; Academic press: London, UK, 2016; pp. 87-105. ISBN 978-0-12-802724-0.

87. McSweneey, P.L.H. Biochemistry of cheese ripening. Int. J. Dairy Technol. 2004, 57, 127-144. [CrossRef]

88. Santiago-López, L.; Aguilar-Toalá, J.E.; Hernández-Mendoza, A.; Vallejo-Cordoba, B.; Liceaga, A.M.; González-Córdova, A.F. Invited review: Bioactive compounds produced during cheese ripening and health effects associated with aged cheese consumption. J. Dairy Sci. 2018, 101, 3742-3757. [CrossRef]

89. Bottari, B.; Levante, A.; Bancalari, E.; Sforza, S.; Bottesini, C.; Prandi, B.; De Filippis, F.; Ercolini, D.; Nocetti, M.; Gatti, M. The Interrelationship Between Microbiota and Peptides During Ripening as a Driver for Parmigiano Reggiano Cheese Quality. Front. Microbiol. 2020, 11, 581658. [CrossRef]

90. Trieu, K.; Bhat, S.; Dai, Z.; Leander, K.; Gigante, B.; Qian, F.; Korat, A.V.A.; Sun, Q.; Pan, X.-F.; Laguzzi, F.; et al. Biomarkers of dairy fat intake, incident cardiovascular disease, and all-cause mortality: A cohort study, systematic review, and meta-analysis. PLoS Med. 2021, 18, e1003763. [CrossRef]

91. Daliri, E.B.M.; Lee, B.H.; Park, B.J.; Kim, S.H.; Oh, D.H. Antihypertensive peptides from whey proteins fermented by lactic acid bacteria. Food Sci. Biotechnol. 2018, 27, 1781-1789. [CrossRef]

92. Fekete, Á.A.; Givens, D.I.; Lovegrove, J.A. Casein-derived lactotripeptides reduce systolic and diastolic blood pressure in a meta-analysis of randomised clinical trials. Nutrients 2015, 7, 659-681. [CrossRef] 
93. Crippa, G.; Zabzuni, D.; Bravi, E.; Piva, G.; De Noni, I.; Bighi, E.; Rossi, F. Randomized, double blind placebo-controlled pilot study of the antihypertensive effects of Grana Padano, D.O.P. cheese consumption in mild-Moderate hypertensive subjects. Eur. Rev. Med. Pharmacol. Sci. 2018, 22, 7573-7581. [CrossRef] [PubMed]

94. Ruiz-Moyano, S.; Gonçalves dos Santos, M.T.P.; Galván, A.I.; Merchán, A.V.; González, E.; de Guía Córdoba, M.; Benito, M.J. Screening of autochthonous lactic acid bacteria strains from artisanal soft cheese: Probiotic characteristics and prebiotic metabolism. LWT 2019, 114, 108388. [CrossRef]

95. Arshad, F.-A.; Mehmood, R.; Hussain, S.; Annus Khan, M.; Khan, M.S. Lactobacilli as Probiotics and their Isolation from Different Sources. Br. J. Res. 2018, 5. [CrossRef]

96. Bajic, S.S.; Djokic, J.; Dinic, M.; Veljovic, K.; Golic, N.; Mihajlovic, S.; Tolinacki, M. GABA-producing natural dairy isolate from artisanal zlatar cheese attenuates gut inflammation and strengthens gut epithelial barrier in vitro. Front. Microbiol. 2019, 10, 527. [CrossRef] [PubMed]

97. Tillisch, K.; Labus, J.; Kilpatrick, L.; Jiang, Z.; Stains, J.; Ebrat, B.; Guyonnet, D.; Legrain-Raspaud, S.; Trotin, B.; Naliboff, B.; et al. Consumption of fermented milk product with probiotic modulates brain activity. Gastroenterology 2013, 144, 1394-1401.e4. [CrossRef] [PubMed]

98. Boricha, A.A.; Shekh, S.L.; Pithva, S.P.; Ambalam, P.S.; Manuel Vyas, B.R. In vitro evaluation of probiotic properties of Lactobacillus species of food and human origin. LWT 2019, 106, 201-208. [CrossRef]

99. Mancini, A.; Carafa, I.; Franciosi, E.; Nardin, T.; Bottari, B.; Larcher, R.; Tuohy, K.M. In vitro probiotic characterization of high GABA producing strain Lactobacilluas brevis DSM 32386 isolated from traditional "wild" Alpine cheese. Ann. Microbiol. 2019, 69, 1435-1443. [CrossRef]

100. Tagliazucchi, D.; Martini, S.; Solieri, L. Bioprospecting for bioactive peptide production by lactic acid bacteria isolated from fermented dairy food. Fermentation 2019, 5, 96. [CrossRef]

101. Mathur, H.; Beresford, T.P.; Cotter, P.D. Health benefits of lactic acid bacteria (Lab) fermentates. Nutrients 2020, 12, 1679. [CrossRef]

102. Linares, D.M.; Gómez, C.; Renes, E.; Fresno, J.M.; Tornadijo, M.E.; Ross, R.P.; Stanton, C. Lactic Acid Bacteria and Bifidobacteria with Potential to Design Natural Biofunctional Health-Promoting Dairy Foods. Front. Microbiol. 2017, 8, 846. [CrossRef]

103. García-Burgos, M.; Moreno-Fernández, J.; Alférez, M.J.M.; Díaz-Castro, J.; López-Aliaga, I. New perspectives in fermented dairy products and their health relevance. J. Funct. Foods 2020, 72, 104059. [CrossRef]

104. Liu, D.; Tong, C. Bacterial community diversity of traditional fermented vegetables in China. LWT-Food Sci. Technol. 2017, 86, 40-48. [CrossRef]

105. Lorn, D.; Nguyen, T.K.C.; Ho, P.H.; Tan, R.; Licandro, H.; Waché, Y. Screening of lactic acid bacteria for their potential use as aromatic starters in fermented vegetables. Int. J. Food Microbiol. 2021, 350, 109242. [CrossRef]

106. Varzakas, T.; Zakynthinos, G.; Proestos, C.; Radwanska, M. Fermented Vegetables. In Minimally Processed Refrigerated Fruits and Vegetables; Yildiz, F., Wiliey, R., Eds.; Springer Science: New York, NY, USA, 2017; pp. 537-584. ISBN 978-1-4939-7018-6.

107. Bousquet, J.; Anto, J.M.; Czarlewski, W.; Haahtela, T.; Fonseca, S.C.; Iaccarino, G.; Blain, H.; Vidal, A.; Sheikh, A.; Akdis, C.A.; et al. Cabbage and fermented vegetables: From death rate heterogeneity in countries to candidates for mitigation strategies of severe COVID-19. Allergy Eur. J. Allergy Clin. Immunol. 2021, 76, 735-750. [CrossRef] [PubMed]

108. Peñas, E.; Martinez-Villaluenga, C.; Frias, J. Sauerkraut: Production, Composition, and Health benefits. In Fermented Foods in Health and Disease Prevention; Frias, J., Martinez-Villaluenga, C., Peñas, E., Eds.; Academic Press: London, UK, 2017; pp. 557-570.

109. He, G.Q.; Liu, T.J.; Sadiq, F.A.; Gu, J.S.; Zhang, G.H. Insights into the microbial diversity and community dynamics of Chinese traditional fermented foods from using high-throughput sequencing approaches. J. Zhejiang Univ. Sci. B 2017, 18, 289-302. [CrossRef]

110. Cai, W.; Tang, F.; Wang, Y.; Zhang, Z.; Xue, Y.; Zhao, X.; Guo, Z.; Shan, C. Bacterial diversity and flavor profile of Zha-Chili, a traditional fermented food in China. Food Res. Int. 2021, 141, 110112. [CrossRef]

111. Mallappa, R.H.; Balasubramaniam, C.; Nataraj, B.H.; Ramesh, C.; Kadyan, S.; Pradhan, D.; Muniyappa, S.K.; Grover, S. Microbial diversity and functionality of traditional fermented milk products of India: Current scenario and future perspectives. Int. Dairy J. 2021, 114, 104941. [CrossRef]

112. Orgeron, R.P., II; Corbin, A.; Scott, B. Sauerkraut: A Probiotic Superfood. Funct. Foods Health Dis. 2016, 6, 536. [CrossRef]

113. Nielsen, E.S.; Garnås, E.; Jensen, K.J.; Hansen, L.H.; Olsen, P.S.; Ritz, C.; Krych, L.; Nielsen, D.S. Lacto-fermented sauerkraut improves symptoms in IBS patients independent of product pasteurisation-a pilot study. Food Funct. 2018, 9, $5323-5335$. [CrossRef]

114. Peñas, E.; Martinez-Villaluenga, C.; Frias, J.; Sánchez-Martínez, M.J.; Pérez-Corona, M.T.; Madrid, Y.; Cámara, C.; Vidal-Valverde, C. Se improves indole glucosinolate hydrolysis products content, Se-methylselenocysteine content, antioxidant capacity and potential anti-inflammatory properties of sauerkraut. Food Chem. 2012, 132, 907-914. [CrossRef]

115. Sawicka, H. Glucosinolates As Natural Plant Substances-Structural and Application Aspects: A Review. J. Cell Tissue Res. 2020, 20, 6919-6928.

116. Raak, C.; Ostermann, T.; Boehm, K.; Molsberger, F. Regular Consumption of Sauerkraut and Its Effect on Human Health: A Bibliometric Analysis. Glob. Adv. Health Med. 2014, 3, 12-18. [CrossRef]

117. Stiemsma, L.T.; Nakamura, R.E.; Nguyen, J.G.; Michels, K.B. Does Consumption of Fermented Foods Modify the Human Gut Microbiota? J. Nutr. 2020, 150, 1680-1692. [CrossRef] 
118. Liu, L.; Du, P.; Zhang, G.; Mao, X.; Zhao, Y.; Wang, J.; Duan, C.; Li, C.; Li, X. Residual nitrite and biogenic amines of traditional northeast sauerkraut in China. Int. J. Food Prop. 2017, 20, 2448-2455. [CrossRef]

119. Park, S.E.; Kwon, S.J.; Cho, K.M.; Seo, S.H.; Kim, E.J.; Unno, T.; Bok, S.H.; Park, D.H.; Son, H.S. Intervention with kimchi microbial community ameliorates obesity by regulating gut microbiota. J. Microbiol. 2020, 58, 859-867. [CrossRef] [PubMed]

120. Park, J.M.; Lee, W.H.; Seo, H.; Oh, J.Y.; Lee, D.Y.; Kim, S.J.; Hahm, K.B. Microbiota changes with fermented kimchi contributed to either the amelioration or rejuvenation of helicobacter pylori-associated chronic atrophic gastritis. J. Clin. Biochem. Nutr. 2021, 69, 96-110. [CrossRef]

121. Park, J.M.; Han, Y.M.; Oh, J.Y.; Lee, D.Y.; Choi, S.H.; Kim, S.J.; Hahm, K.B. Fermented kimchi rejuvenated precancerous atrophic gastritis via mitigating Helicobacter pylori-associated endoplasmic reticulum and oxidative stress. J. Clin. Biochem. Nutr. 2021, 69, 158-170. [CrossRef] [PubMed]

122. Choi, I.H.; Noh, J.S.; Han, J.S.; Kim, H.J.; Han, E.S.; Song, Y.O. Kimchi, a Fermented Vegetable, improves serum lipid profiles in healthy young adults: Randomized clinical trial. J. Med. Food 2013, 16, 223-229. [CrossRef]

123. Lee, S.Y.; Sekhon, S.S.; Ko, J.H.; Kim, H.C.; Kim, S.Y.; Won, K.; Ahn, J.Y.; Lee, K.; Kim, Y.H. Lactic acid bacteria isolated from kimchi to evaluate anti-obesity effect in high fat diet-induced obese mice. Toxicol. Environ. Health Sci. 2018, 10, 11-16. [CrossRef]

124. An, S.Y.; Lee, M.S.; Jeon, J.Y.; Ha, E.S.; Kim, T.H.; Yoon, J.Y.; Ok, C.O.; Lee, H.K.; Hwang, W.S.; Choe, S.J.; et al. Beneficial effects of fresh and fermented kimchi in prediabetic individuals. Ann. Nutr. Metab. 2013, 63, 111-119. [CrossRef]

125. Sivamaruthi, B.S.; Kesika, P.; Prasanth, M.I.; Chaiyasut, C. A mini review on antidiabetic properties of fermented foods. Nutrients 2018, 10, 1973. [CrossRef]

126. Henry, C.J. Functional foods. Eur. J. Clin. Nutr. 2010, 64, 657-659. [CrossRef] [PubMed]

127. Han, Y.M.; Park, J.M.; Jeong, M.; Yoo, J.H.; Kim, W.H.; Shin, S.P.; Ko, W.J.; Hahm, K.B. Dietary, non-microbial intervention to prevent Helicobacter pylori-associated gastric diseases. Ann. Transl. Med. 2015, 3, 122. [CrossRef]

128. Han, Y.M.; Kang, E.A.; Park, J.M.; Oh, J.Y.; Lee, D.Y.; Choi, S.H.; Hahm, K.B. Dietary intake of fermented kimchi prevented colitis-associated cancer. J. Clin. Biochem. Nutr. 2020, 67, 263-273. [CrossRef] [PubMed]

129. Kim, H.Y.; Park, K.Y. Clinical trials of kimchi intakes on the regulation of metabolic parameters and colon health in healthy Korean young adults. J. Funct. Foods 2018, 47, 325-333. [CrossRef]

130. Seong, G.; Lee, S.; Min, Y.W.; Jang, Y.S.; Kim, H.S.; Kim, E.J.; Park, S.Y.; Kim, C.H.; Chang, D.K. Effect of heat-killed lactobacillus casei dkgf7 on a rat model of irritable bowel syndrome. Nutrients 2021, 13, 568. [CrossRef] [PubMed]

131. Chung, H.G.; Min, Y.W.; Lee, C.; Hong, S.N.; Won, J.Y.; Jang, J.A.; Kim, C.H.; Chang, D.K. Effects of Novel Probiotics in a Murine Model of Irritable Bowel Syndrome. Korean J. Gastroenterol. 2020, 75, 141-146. [CrossRef]

132. Graudal, N.; Jürgens, G. Conflicting Evidence on Health Effects Associated with Salt Reduction Calls for a Redesign of the Salt Dietary Guidelines. Prog. Cardiovasc. Dis. 2018, 61, 20-26. [CrossRef]

133. Septembre-Malaterre, A.; Remize, F.; Poucheret, P. Fruits and vegetables, as a source of nutritional compounds and phytochemicals: Changes in bioactive compounds during lactic fermentation. Food Res. Int. 2018, 104, 86-99. [CrossRef] 